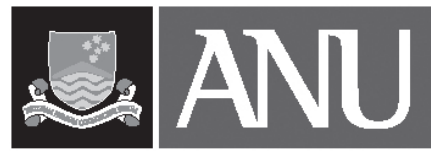

THE AUSTRALIAN NATIONAL UNIVERSITY

AUSTRALIA-JAPAN RESEARCH CENTRE

ANU COLLEGE OF ASIA \& THE PACIFIC

CRAWFORD SCHOOL OF ECONOMICS AND GOVERNMENT

\title{
A TALE OF PORK PRICES: EVASION AND ATTENUATION OF A JAPANESE TARIFF
}

Kazuki Onji

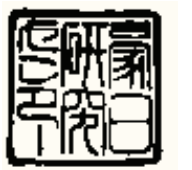

ASIA PACIFIC ECONOMIC PAPERS

No. 382, 2009 

ASIA PACIFIC ECONOMIC PAPER NO. 382

2009

\title{
A tale of pork prices: evasion and attenuation of a Japanese tariff
}

\author{
Kazuki Onji*
}

\author{
AUSTRALIA-JAPAN RESEARCH CENTRE \\ CRAWFORD SCHOOL OF ECONOMICS \& GOVERNMENT \\ ANU COLLEGE OF ASIA AND THE PACIFIC
}


This work is copyright. Apart from those uses which may be permitted under the Copyright Act 1968 as amended, no part may be reproduced by any process without written permission.

Asia Pacific Economic Papers are published under the direction of the Editorial Committee of the Australia-Japan Research Centre (AJRC). Members of the Editorial Committee are:

Professor Jenny Corbett

Executive Director

Australia-Japan Research Centre

The Australian National University, Canberra

Professor Emeritus Peter Drysdale

Crawford School of Economics and Government

The Australian National University, Canberra

Professor Christopher Findlay

Professor of Economics

University of Adelaide

Adelaide, South Australia

Professor Stuart Harris

Department of International Relations

The Australian National University, Canberra

Dr Kazuki Onji

Crawford School of Economics and Government

The Australian National University, Canberra

Papers submitted for publication in this series are subject to double-blind external review by two referees. The views expressed in APEPs are those of the individual authors and do not represent the views of the Australia-Japan Research Centre, the Crawford School, or the institutions to which authors are attached.

The Australia-Japan Research Centre is part of the Crawford School of Economics and Government, The Australian National University, Canberra.

ISSN 07288409

ISBN 978-0-86413-336-6

Australia-Japan Research Centre

Crawford School of Economics and Government

The Australian National University

Canberra ACT 0200

Telephone: (61 2) 61253780

FACSIMILE: (61 2) 61250767

E-MAIL:AJRC@ANU.EDU.AU

URL: HTTP://WWW.CRAWFORD.ANU.EDU.AU 


\section{A Tale of Pork Prices: Evasion and Attenuation OF A JAPANESE TARIFF}

This paper empirically examines the effectiveness of a safeguard tariff in the Japanese market for imported pork parts. The goals are, first, to consider a refinement to the traditional market-based method for evasion detection, and, second, to apply the method in a setting where evasion is suspected to be widespread. Utilising a within-pig variation in tariff burdens and the timing of safeguard invocations, I examine a panel of monthly wholesale prices on narrowly-defined pork products from 2001 through 2008. The results are consistent with a hypothesis that a widespread evasion nullified the safeguard tariff on pork, and are robust to a range of alternative explanations including the adjustment of profit margins by traders. Safeguard tariffs appear to be a simple mechanism, but behavioural responses can undo the policy intent.

Keywords: safeguard tariff, price disparity, tax incidence

JEL Classification: H26, H22, F13, L11, Q17

* This research developed through conversations with visitors to the Australia-Japan Research Centre in ANU while I was a postdoctoral fellow at the Centre. Special thanks are due to Yoshibisa Godo, who introduced me to people at a NPO organised by pork traders. I wish to thank for comments and suggestions Bolong Cao, Jenny Corbett, Roger Gordon, David Vera, and seminar participants at Australian National University, Kent State University, Ohio University, and JSAA 2009. Hiroshi Kobayashi and the student members at the Japan Meat Trade Center helped me collect data from their archive. A financial support from the Japanese Economy Research Foundation is gratefully acknowledged.

+ Crawford School of Economics and Government, Australian National University, Building 13, ACT0200, Australia; Tel.:

+61-2-6125-0134; Fax: +61-2-6125-0767; email: Kazuki.Onji@anu.edu.au

\section{Introduction}

Tariffs are important sources of government revenue for countries with insufficient infrastructures for collecting taxes. Baunsgaard and Keen (2005) note that sub-Saharan countries in Africa collect, on average, a quarter of government revenue from levies on international trade, and find that low-income countries have on average recovered only 30 per cent of revenue lost from trade liberalisation. Consequently, the evasion of custom duties had received considerable research attention (for example Bhagwati, 1974). Contemporary 
empirical research on tariff evasion builds on the previous literature but is distinct in the extensiveness of data analysed, in the application of recently developed statistical techniques, and in the careful choice of research settings. ${ }^{1}$ Particularly, studies that identify evasion through gaps in matched-partner trade statistics have flourished (Fisman and Wei 2005; Mishra, Subramanian, and Topalova, 2008; Javorcik and Narciso, 2008) in the backdrop of the international harmonisation of the product code in the trade statistics and the availability of trade flow statistics through the United Nations' COMTRADE database. Those studies have provided insights into the relationship between the evasion of tariff with the tax rate, degree of law enforcement, and product differentiation.

As powerful as it may be, the price gap analysis has its limitations. First, as noted repeatedly, the cross-country discrepancies between trade statistics are caused by freight, services charges, timing of trade, product classification, among others factors. Bhagwati (1964) emphasises in his seminal paper that the 'price gap provides, not a conclusive proof, but only a strong indication of the presence of under-invoicing of imports'. The study by Fisman and Wei (2005) reduces this concern by focusing on the border trade between Hong Kong and China. Second, if goods were imported through smugglers operating stealthily in the night, rather than under-invoiced at official ports of entry, an approach based on an official statistics fails to capture the behaviour (Cooper, 1974). Last, but not least important, price gaps provide no information about the effects of evasion on traded prices - the key in understanding the welfare consequence of smuggling, according to theoretical studies (Bhagwati and Hansen, 1973; Pitt, 1981;Thursby, Mutti, and Thursby, 1991; Lovely, 1994). Essentially, welfare improves if the reduction in the distortionary impacts of tariffs is larger than the resource wasted in conducting smuggling. Analyses of trade statistics are silent on the market consequence of tariff evasion.

Cooper (1974) and Pitt (1981a,b) have suggested a market-based method for evasion detection referred to as a price disparity analysis; this paper aims to refine this complementary method. The price disparity analysis infers the presence of tariff evasion from the difference between the prevailing market price of a commodity and the counterfactual price that would have prevailed had there been no tariff evasion. In an early application in Indonesia, Cooper (1974) finds price disparities in a number of narrowly defined commodities during the 1950s and 1960s - a time period in which smuggling is thought to be pervasive - confirming the informativeness of the analysis. Cooper (1974) approximates the counterfactual price in a crude manner, arbitrarily assuming a uniform mark-up of 25 per cent across a range of products. Furthermore, consider a setting where exporters have market power. By presuming that the price respond one-for-one to changes in tariff, as is often assumed to be the case, the approach erroneously attributes price disparities as due to the evasion of custom duties when in fact the pricing behaviour of exporters is the real 
cause. ${ }^{2}$ To my knowledge, the price disparity analysis has not received a contemporary make-over as in the price gap analysis.

To address these concerns, this paper proposes a new approximation of the counterfactual price, drawing from the literature, which was not well developed at the time of the earlier price disparity studies, on the exchange-rate pass-through (ERPT). Feenstra (1989) shows that the changes in tariffs and exchange rates have the same impact in an oligopoly market. While this result is derived under a set of assumptions, empirical studies suggest that an ERPT coefficient provides a first approximation of a tariff-rate pass-through (TRPT) coefficient (Feenstra, 1989; Winkleman and Winkleman 1998). This paper considers an identification strategy whereby the evasion is attributed to the difference between observed price levels and a theoretical benchmark based on ERPT. In the empirical public finance literature, behavioural responses, including commodity tax evasion, are identified through the deviation of the observed impacts of taxes from theoretical benchmarks (Marion and Muehlegger, 2008; Chetty, Looney, and Kroft, 2007). ${ }^{3}$ The contribution of this paper is to suggest a benchmark.

The setting to apply this refined price disparity analysis is the Japanese market for imported pork parts. An advantage in focusing on the Japanese tariff on pork parts is that, due to the complexity in the tariff design, the tariff system generates 'within-pig variation' in tax rates. Under a variable tariff levy adopted in the market for imported pork, lowvalue pork parts are taxed more heavily than high-value pork parts, creating incentives for smuggling low-value pork parts. Furthermore, Japan had negotiated a special agreement on safeguard clause in the WTO, allowing Japan to temporarily raise tariffs when import volume surges. The WTO records 89 cases of safeguard measures invoked over 1995 through 2008 around the world. ${ }^{4}$ In the current setting, the invocation of the safeguards in the period 2001-2004 led to a 24.6 per cent increase in average import value at ports of entry. Thus, the institutional setting creates cross-section as well as time variations in tariff, providing an interesting setting to examine the performance of the price disparity analysis. Additionally, a focus on a specific type of commodities allows for a straightforward verification of the price disparity analysis with the price gap analysis.

The topic for this paper has relevance to a policy debate in Japan. In the backdrop of rising pork imports, the pork tariff has generated controversy. ${ }^{5}$ While economists and the press generally consider the Japanese pork tariff needs to be reformed, ${ }^{6}$ the producer groups have managed to maintain the status quo. In May 2007, a report submitted by the Council on Economic and Fiscal Policy, a Japanese equivalent of the Economic Council of the President in the United States, argued that the complexity with tariff systems causes evasion, and recommended repealing the variable levy. The producer group responded strongly to this report. ${ }^{7}$ In the reform agenda adopted by the Japanese Cabinet in June 
2007, the phrase was toned down, stating that the variable levy is to be reviewed (Cabinet Office 2007:16). Despite this policy interest, the impacts of the variable levy on firm behaviour are not formally documented in academic studies. ${ }^{8}$ During a Diet Meeting in 2005, a politician demanded to know the effect of evasion on the price levels, and a representative from the Ministry of Agriculture, Forestry and Fisheries answered that it is undeniable that there are some effects (of tariff evasion) on the pork prices in the domestic markets but it is difficult to quantitatively assess the impacts. ${ }^{9}$ This paper aims to offer such an assessment.

In summary, this paper examines an unbalanced panel of monthly prices of finely disaggregated commodities from three source countries traded at wholesale markets around Japan from 2001 through 2008. Under the full compliance to the law, the tax hike would have led to around 12.3 to 17.2 per cent increase in traded price for a sensible range of TRPT parameters. In an analysis that allows for unobserved country-year specific cost shocks, the disparity between the observed prices and predicted prices is found to be statistically significant for a sample of low-value pork, suggesting a pervasive evasion. Alternative explanations are unlikely to account for the disparity. The results also indicate that the strengthening of enforcement has had a statistically significant impact on the prices of frozen pork. Thus, this study finds that the evasion of the variable levy have attenuated the impact of safeguard tariffs in the Japanese imported pork market in the early 2000s. This result is corroborated by the price gap analysis, which finds an evasion epidemic of 1999-2005: An estimated the total amount of tariff evaded on Denmark frozen pork is 293 billion yen over 1998-2007. This amount is 6 times as much as the revenue collected from those commodities in the period. Consequently, the result suggests that, as a result of the evasion, the safeguard did not result in inefficiency through interfering in the price mechanism, or through affecting other margins of adjustments, to the extent that would have arose under the full compliance.

This paper adds to recent empirical studies on tax evasion, particularly those that examine the effects of enforcement on firm behaviour (Yang, 2008; Marion and Muehlegger, 2008; Mishra, Subramanian, and Topalova, 2008). ${ }^{10}$ The current study corroborates the previous findings that enforcement affects firms' decisions to engage in tax evasion. One distinctive feature with this paper is in documenting a case where, due to pervasive evasion, prices do not respond one-for-one to changes in tariff. A number of studies point out that the tax incidence, while theoretically well understood, is not well documented empirically (Besley and Rosen, 1999; Alm, Sennoga, and Skidmore, 2009). In understanding tax incidence, the economic reasoning point us to the demand elasticity and the market power of suppliers, but the results in this paper remind us that behavioural responses that operates outside the conventional price mechanism can induce first-order effects on the 
formation of market prices. ${ }^{11}$

The rest of the paper is organised as follows. Section 2 discusses the pork market and policies in Japan. Section 3 describes the data. Section 4 examines the responses of wholesale prices to the invocation of safeguards, considers non-evasion based explanation for an observed lack of price response, and presents a price gap analysis. Section 6 concludes.

\section{Background on the Japanese market for imported pork}

\section{Industry characteristics}

Japan in 2008 imports about a half of domestic pork consumption from abroad, a substantial increase from 1990 when the import share was about a quarter. ${ }^{12}$ The major source countries are the Denmark, United States, and Canada, which have the import share in 2000 of 32.6, 29.0, and 17 per cent respectively. Imports from neighbouring countries such as Taiwan and Korea are limited due to the outbreak of foot and mouse disease outbreaks in these countries. About 70 per cent of pork imports are frozen meat, which are inputs for manufacturing processed meats, such as ham and sausages. The downstream market is dominated by large meat processing companies: the five-firm concentration ratio in 1999 was 56.7 per cent. The meats are imported by trading intermediaries, which are relatively small — there were about 60 companies importing pork in 2000. Some of the trading intermediaries are subsidiaries of the downstream manufacturers.

\section{The variable levy on imported pork}

The European Union used to adopt a variable import levy on some of its agricultural commodities (Harris, Swinbank, and Wilkinson, 1983). The Japanese tariff on pork is a version of the variable import levy (Obara, Dyck, and Stout, 2003). Figure 1 illustrates the relationship between the imported price (CIF) and after-tax price. The unit is in per kilo of pork parts. There are three segments: If the average price per kilo is beyond the gate price of 524 yen, there is an ad valorem tax of 4.3 per cent per kilo; between 524 and 65 yen, the levy is the difference between 546.5 and CIF; below 65 yen, there is unit tax of 482 yen per kilo. Except for dressed carcasses for which the gate price of 393 per kilo applies, any pork parts are taxed under this scheme. In short, the system sets a price floor — officially called a standard import price — on pork parts imports.

There are concerns about several types of behavioural responses. First, since lowvalue pork parts are taxed heavily under the variable levy, there are incentives to smuggle low-value parts disguised as high-value parts. Given that much of the import demand is 
Figure 1: Variable import levy on pork

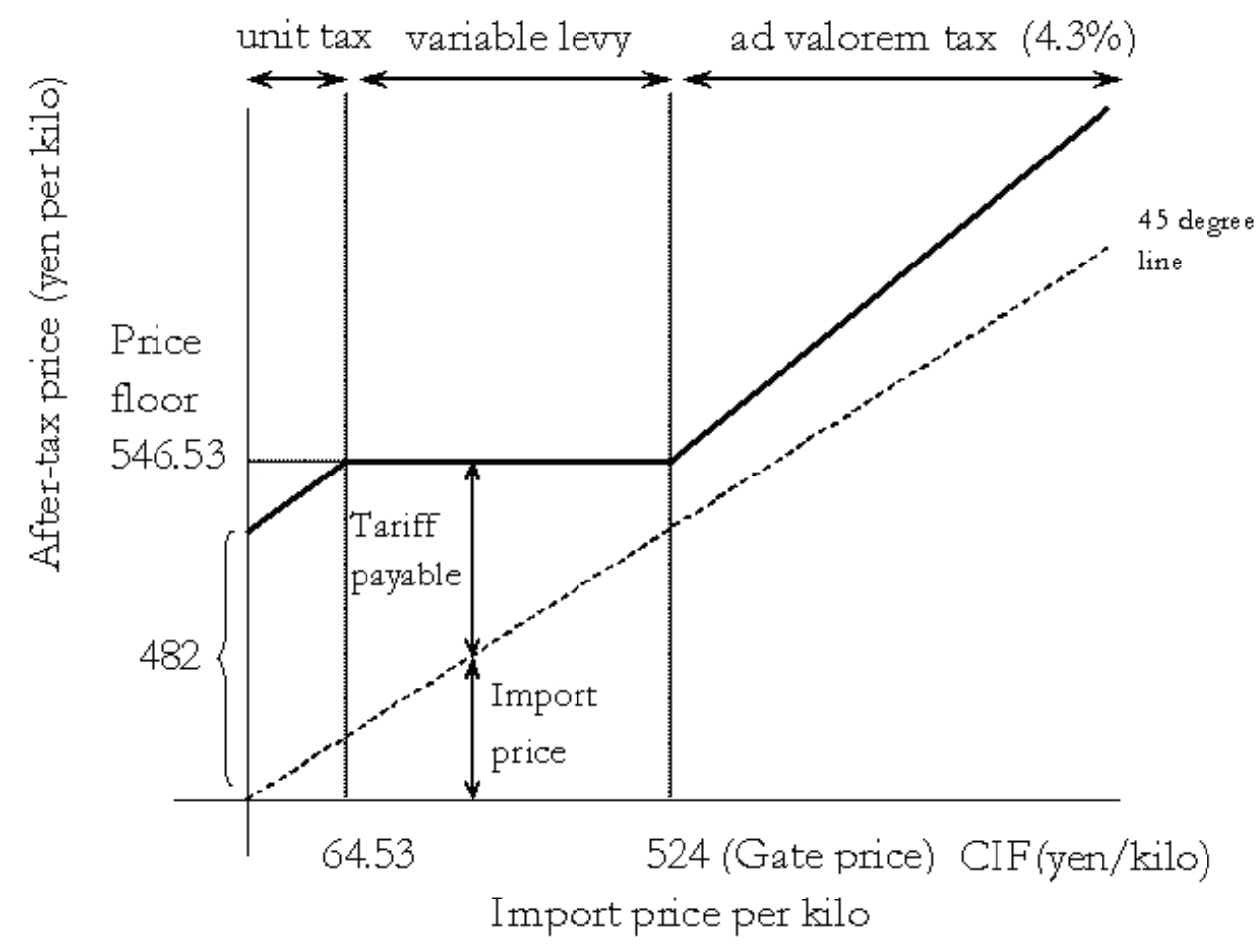

Source: Author's Caculations

for low-value frozen pork parts for processing into ham and sausages, the incentives for smuggling are relevant. In light of the finding by Fisman and Wei (2005) that suggests higher tariff rates induce more traders to evade tariffs, it is plausible to expect that traders attempt to evade duties. Second, there is de facto permission for mixing different parts shipped from a same origin country by the same storage method. This means that traders can combine frozen tenderloin and belly from Denmark to increase the weighted average price per invoice. This mixing strategy is thought to be a common practice. ${ }^{13}$ Tanaka and Mori (2001) show that high-value meats from the United States are traded at discount on the data from 1998 through 2000, and interpret the result as suggesting that the traders import high-value parts for tax purposes despite smaller domestic demand for high-value imported pork parts. Third, according to a trader whom I interviewed, the system discourages traders from claiming refund for the damaged commodities on arrival, since claiming damage reduces the value to be declared to the Japanese custom and thereby increases the amount of tax liability. Thus, this variable levy creates a variety of incentives that are not captured in the price mechanism. 


\section{The safeguard of a domestic swinery}

Several changes to the price floor provide a useful setting to implement a study on price disparities. The WTO agreement permits Japan to invoke two types of safeguard tariffs on pork: gate-price safeguard (SG) and special safeguard (SSG). ${ }^{14}$ SG raises the price floor to 681 yen from 546.53 yen and is invoked if import surges beyond a trigger level - the import volume above 119 per cent of the average volume for the past three years. The quantity test is based on the cumulative volume since the beginning of the Japanese Fiscal Year (JFY), which is from April to March. Once invoked, SG lasts till the end of JFY and is removed from the beginning of the following JFY. The focus of this study is the SG invoked in 2001-2004 based on the availability of commodity price data. SSG increases the tariff rate to 6.5 per cent and was invoked in January-March 1997.

Figure 2 shows the impact of the changes in gate price on the reported import perkilo price (CIF) from 1988 to 2008. Unlike usual time series data on prices, the pattern is quite unusual in tracing the gate price very closely. The solid and dotted line shows, respectively, the average price for invoices declared above and below the gate price. The proximity of two lines indicates the distribution of declared price that is dense around the gate price. Two lines trace the reduction in the gate price until 2000 under the WTO agreement, as well as the invocation of SG in JFY 1995, 1996, 1997 and 2000-2004.

Figure 2: Average declared price of frozen pork imports

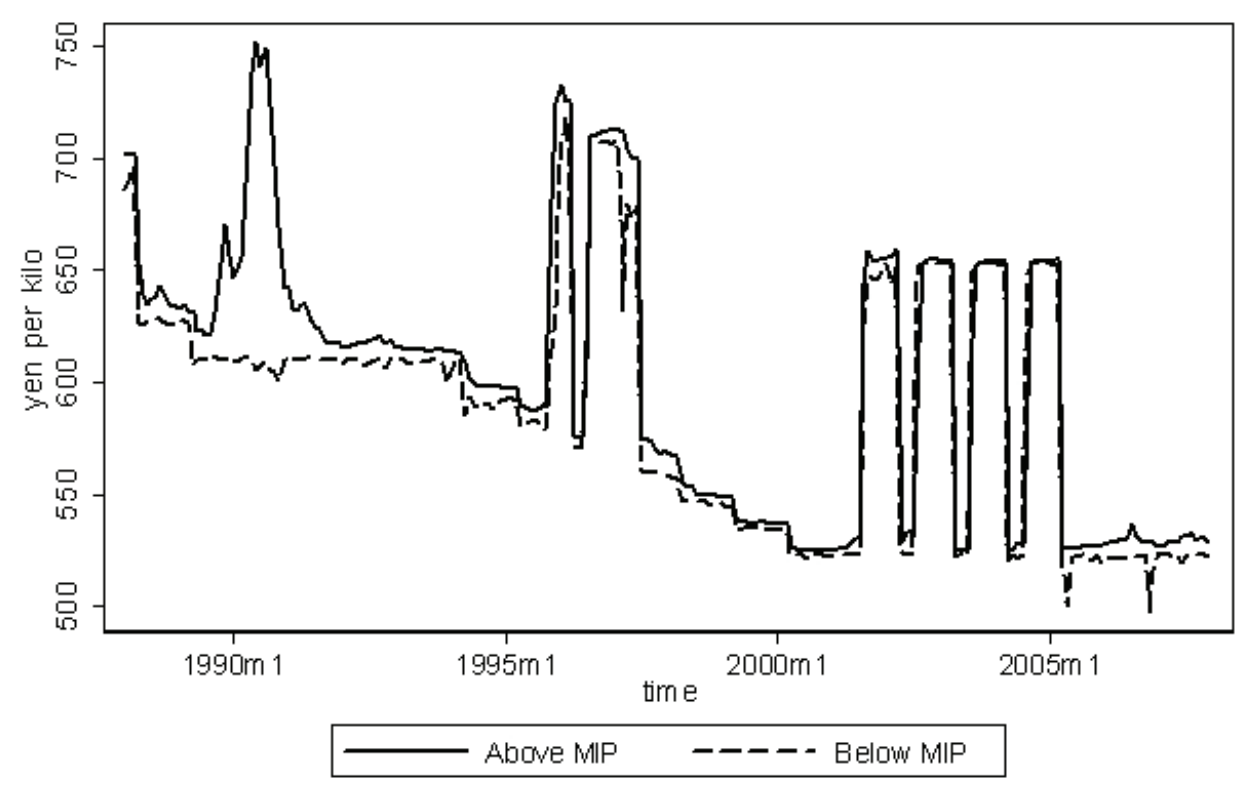

Source: Author's Caculations 
As the timing of the safeguard removal is known, traders are expected to adjust the timing of trade to take advantage of a lower tariff after safeguard removal at the end of March. Safeguards were invoked in 2001 after there was a surge in imports that was intended to beat the import restrictions from Europe due to the outbreak of the foot and mouth disease. Thus, hoarding behaviour is a relevant consideration in the analysis of the price disparity.

\section{Law enforcement}

The evasion of pork tariffs is an chronic issue since the introduction of the variable levy in 1974. In a recent criminal case, a meat wholesaler was accused in 2007 of evading 5.9 billion yen over 23 month (April 2003-February 2005). Relative to 16.1 billion yen collected from tariff revenue on pork in 2005 , the amount from a single case was already substantial. A casual examination of court cases suggests that the enforcement strengthened during 2005. ${ }^{15}$ The total amount of tax evaded in the five large cases of criminal indictments from 1999 through 2004 was 740 million yen whereas the total amount was 24.5 billion yen for five cases from May 2005 through February 2007; for the first time since the enactment of the custom law, a warehouse company caught with a tariff evasion had its permission to conduct custom clearance services revoked in December 2006. Correspondingly, a heavier penalty on tariff evasion was enacted in March 2005 and was enforced from October 2005. Previously, the penalty was at a maximum 5 years of imprisonment and/or a maximum fine of 5 million yen, in addition to a penalty from 10 per cent of the correct tax liability. The penalty tax was increased to 35 per cent in the reform of 2005 . In addition, the Ministry of Agriculture, Forestry and Fisheries nudged traders for better compliance through distributing a leaflet in April-May 2005. The leaflet contains texts that call for a better compliance and inform traders about the legislative change on penalties. Thus, the policy environment changed in the mid-2000s.

\section{Data}

The data source is the monthly product-level price data on pork parts published by the Japan Meat Trade Centre (JMTC), which organises wholesale markets for domestic as well as imported meats in several locations around Japan. The main advantage of the JMTC data over other information source on pork price is the level of disaggregation; some wholesale markets publicise the prices of domestic dressed carcasses and sometimes prices of meat parts, but the JMTC is, to my knowledge, the only data that allows us to make a distinction between, for example, the prices of chilled tenderloin from the United States and frozen belly from Denmark. ${ }^{16}$ The main trading results at JMTC are published daily in the press, 
including the Nibon Keizai Shimbun, the Japanese-equivalent of the Wall Street Journal. Transactions of imported pork are, however, typically over-the-counter trades, meaning downstream meat processors deal directly with trading intermediaries rather than making purchases at wholesale markets (Kaku and Fukase 2002). In 2005, the total volume of imported pork traded at the JMTC was 8.2 thousand tons, which is just 0.94 per cent of the total imported volume of frozen and chilled pork parts declared at the custom in the year. An ideal data is the trade information of private parties, but the arbitrage would prevent a divergence of JMTC prices from trades conducted elsewhere. ${ }^{17}$ Furthermore, the JMTC publication is used as reference prices by transacting parties.

I use the monthly weighted-average prices from three markets at varying time lengths: Kawasaki, located near Tokyo, (2001:2-2008:7), Osaka (2003:3-2008:7) and Nagoya (2005:3-2008:7). JMTC has provided the data in electric format from 2005 onwards, and I obtained photocopies of the trade archives at their business office in Kawasaki for the earlier data. Data contains six pork parts (back ribs, belly, butt, collar, loin, and tender loin), two storage methods (frozen and chilled), and three countries of origin (Canada, Denmark, and United States). Other sources of data used in this study are in the data appendix. Table 1 shows the summary statistics.

Table 1: Summary statistics

$\begin{array}{lll}\text { Mean S.D. N } & \end{array}$

Frozen

$\begin{array}{lccc}\text { Backribs } & 580.6 & 37.7 & 196 \\ \text { Belly } & 589.8 & 39.9 & 544 \\ \text { Butt } & 577.8 & 43.5 & 90 \\ \text { Collar } & 548.0 & 82.5 & 196 \\ \text { Tender Loin } & 811.5 & 54.3 & 344\end{array}$

Chilled

$\begin{array}{llll}\text { Backribs } & 721.6 & 40.2 & 196 \\ \text { Belly } & 749.8 & 27.3 & 252 \\ \text { Butt } & 704.9 & 33.3 & 155 \\ \text { Loin } & 698.4 & 39.0 & 196 \\ \text { Tender Loin } & 936.1 & 73.6 & 351\end{array}$

Exchange rates

$\begin{array}{lccc}\text { JPY/CAD } & 91.3 & 12.4 & 90 \\ \text { JPY/DKK } & 18.4 & 2.4 & 90 \\ \text { JPY/USD } & 115.6 & 7.3 & 90\end{array}$




\section{Analyses}

\section{Visual inspection and a preliminary test}

Figure 3 plots the weighted average prices of frozen pork belly, along with those of frozen tenderloin, imported from Denmark and traded at the Kawasaki market from 2001:2 through 2008:7. I focus on these products in a preliminary analysis since about 70 per cent of pork imports in 2000 are frozen, and 46 per cent of them originate in Denmark. The dotted lines show the levels of price floors and the timing of SG invocations over August-March in 2001, 2002, 2003, and 2004. Note that the price of belly is well below the price floor during the safeguard, but tenderloin is traded above the price floor. Thus, under full compliance, we would expect the belly price to be affected by SG but not the tenderloin price. Recall that the declared prices on frozen pork parts changed sharply during SG. Here, SG appears to have no effects on the market price of belly.

\section{Figure 3: Frozen pork from Denmark: Tokyo market}

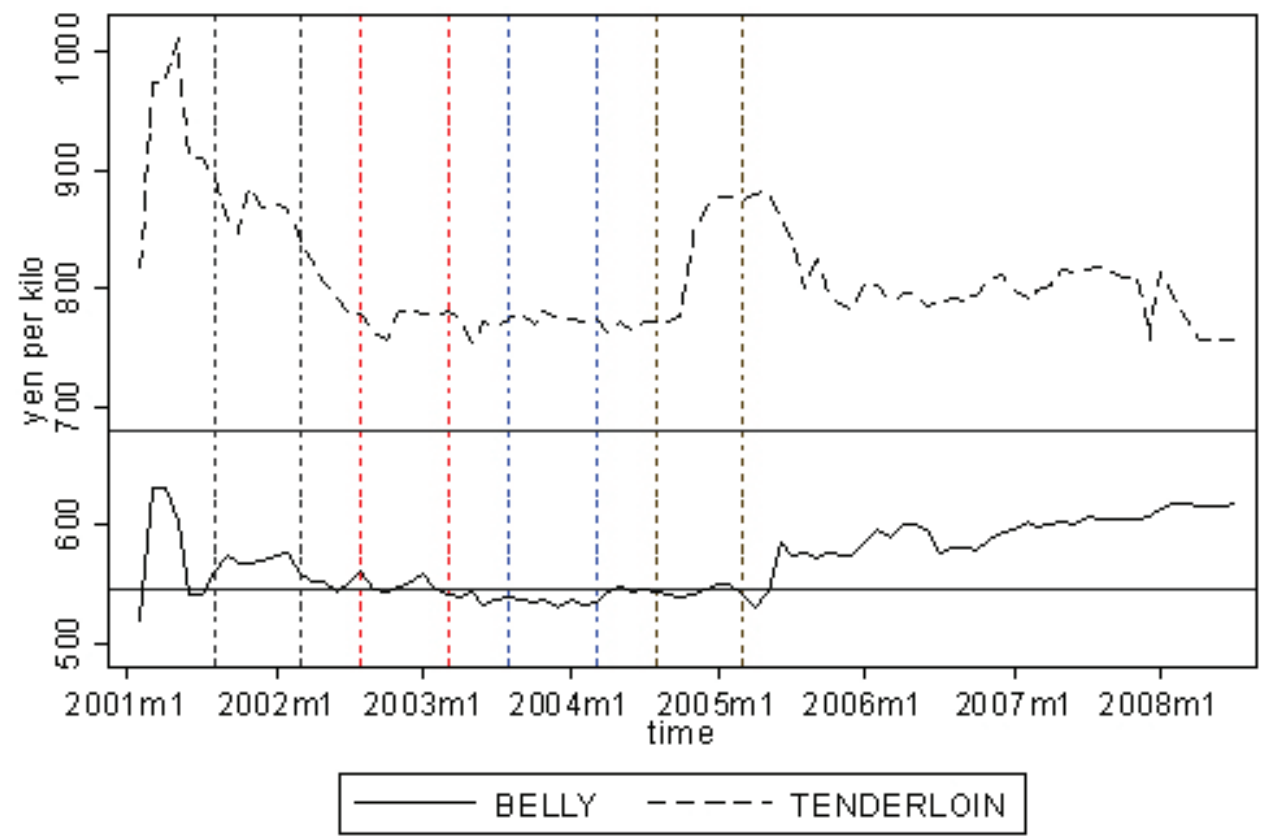

Source: Author's Caculations

To formalise this observation, I consider modeling the belly-tenderloin relationship in a cointegration regression. ${ }^{18}$ Since those belly and tenderloin are produced in Denmark and might originate from identical animals, those commodities are, in theory, subject to similar shocks (for example fluctuations in feed prices). Indeed, a sharp rise in 2001 for both commodities is caused by a contraction in supply due to the food and mouth disease 
outbreak in Europe that led to a temporary suspension of Denmark import. The ban was lifted in one month. The pattern suggests a long-term relationship between the prices of these closely-related commodities. It is thus sensible to expect these prices to be co-integrated. Under a full compliance to the tariff change, then, we would expect the relative prices of those commodities to be affected due to the differential in tax treatments of those goods.

The framework for the analysis is the cointegration regression with a known structural break. If SG had its intended effects - to penalise cheap imports - we would expect a break in the cointegrating relationship between belly and tenderloin. I fit a dynamic OLS with a structural break following the application in Hayashi (2000). Standard tests showed that two series are nonstationary and are cointegrated. ${ }^{19}$

$$
\begin{aligned}
p_{2 t}= & \mu+\gamma p_{1 t}+\delta_{0} D_{t}+\delta_{1} p_{1 t} D_{t}+ \\
& \beta_{p, 0} \Delta p_{1 t}+\beta_{p,-1} \Delta p_{1 t+1}+\beta_{p,-2} \Delta p_{1 t+2}+\beta_{p, 1} \Delta p_{1 t-1}+\beta_{p, 2} \Delta p_{1 t-2}+v_{t}
\end{aligned}
$$

$D_{\mathrm{t}}$ takes the value of 1 while $\mathrm{SG}$ is invoked (that is August to March, every JFY from 2001 through 2004). For modeling convenience, this formulation treats all periods of SG as a single regime. $p_{1 \mathrm{t}}$ and $p_{2 \mathrm{t}}$ are, respectively, the price of belly and tenderloin in log. $\delta_{0}$ and $\delta_{1}$ are the parameter of interest since they capture changes in the cointegrating relationship. $v_{t}$ is a white noise. The lag and lead terms in a dynamic OLS regression are included to deal the serial correlation issue. Appropriate standard errors are calculated following Hayashi (2000).

A structural change is tested with the Chow test. The null hypothesis is the safeguard having no effects on the cointegrating relationship $\left(\delta_{0}=\delta_{1}=0\right)$. A non rejection of the null will be interpreted as a pattern consistent with the attenuation of safeguard due to a host of reasons that I am not distinguishing at this stage. Below, I attempt to distinguish alternative explanations, including the tariffevasion, adjustment of profit margins, hoarding, and mixing strategy. Notice that this approach presumes guilty by taking pervasive evasion as a maintained hypothesis. A preferred approach, to be explored below, would be to take no evasion as a null (Marion and Muehlegger, 2008). Table 2 presents the results. 
Asia Pacific Economic Papers

Table 2: Dynamic Ordinary Least Square Estimates

Dependent variable: LOGTLOIN, DENMARK FROZEN

\begin{tabular}{|c|c|c|c|c|c|}
\hline \multirow{2}{*}{ Variables } & \multicolumn{4}{|c|}{ Break point } & \\
\hline & Safeguard & & Safeguard & 2005.6 & \\
\hline BELLY & $\begin{array}{c}0.064 \\
(0.390)\end{array}$ & & $\begin{array}{c}3.025 \\
(3.989)\end{array}$ & $\begin{array}{c}2.135 \\
(0.813)\end{array}$ & ** \\
\hline REGIME & $\begin{array}{r}-11.116 \\
(5.916)\end{array}$ & + & $\begin{array}{c}6.327 \\
(26.502)\end{array}$ & $\begin{array}{l}14.516 \\
(7.546)\end{array}$ & + \\
\hline BELLY $\times$ REGIME & $\begin{array}{c}1.764 \\
(0.937)\end{array}$ & + & $\begin{array}{l}-1.000 \\
(4.204)\end{array}$ & $\begin{array}{c}-2.301 \\
(1.188)\end{array}$ & + \\
\hline WALD STATISTIC & $\begin{array}{c}4.193 \\
{[0.123]}\end{array}$ & & $\begin{array}{c}0.142 \\
{[0.931]}\end{array}$ & $\begin{array}{c}7.049 \\
{[0.029]}\end{array}$ & * \\
\hline Sample period & $01: 4-08: 5$ & & $01: 4-05: 3$ & $01: 4-08: 5$ & \\
\hline
\end{tabular}

Note: Rescaled standard errors are in parentheses. P-values for the Wald statistic are in brackets.

Source: Author's Calculations

The estimate from a baseline regression (Column 1) indicates a change in the cointegrating vector in an unexpected direction - we would expect that the belly-tenderloin price gap to narrow but the implied spread between two commodities becomes wide. A likely cause is the strengthening of enforcement. The increase in belly price in 2005 roughly coincides with the introduction of heavier penalty and prominent criminal cases. I have tried excluding the sample period after mid-2005 with a caution that the power of the test is likely to be low due to a small sample size (Column 2). Estimated parameters are not significant, and Chow test indicates a lack of structural break. I have tried a specification with a break point at June 2005 (Column 3). The model indicates a significant change in the cointegrating relationship after the mid-2005 in an expected direction. In sum, this preliminary analysis confirms, though with caution, the visual inspection showing the lack of price response to SG. Instead, the stronger enforcement appears to have affected the price of frozen belly imported from Denmark.

While the finding of no structural change is consistent with the evasion of tariff, the attenuation may be caused by other forms of behavioural response. I examine other explanations below. 


\section{Is the lack of response due to the adjustment of the profit margin?}

\section{Exchange-rate pass-through coefficient as an approximation}

The lack of price response may be due to traders bearing the tax incidence by adjusting profit margins in response to SG. This section considers the role of pricing behaviour in attenuating SG tariffs. The proposed empirical approach is in line with Marion and Muehlegger (2008) and Chatty, Looney, and Kroft (2007). As discussed already, in these studies, different types of behavioural responses are expected to weaken the response of some variables to taxes. To identify the behavioural response, the estimates of the tax effects are compared with a benchmark for which the magnitudes are theoretically equivalent in the absence of the particular behavioural response. ${ }^{20}$

A benchmark considered in this paper is the degree of exchange rate pass-through (ERPT). Theoretical and empirical bases render ERPT coefficients a reasonable approximation for tariff rate pass-through (TRPT) coefficients. Feenstra (1989) proposes the symmetry of ERPT and TRPT in the following model of an exporting firm whose objective is to maximize an expected profit in the unit of foreign currency.

$$
\underset{p}{\operatorname{Max}}[e /(1+\tau)]\{p x(p, q, I)-c(x, w)[(1+\tau) / e]\}
$$

$e$ denotes an expected exchange rate in the unit of foreign currency per unit of home currency. The objective of the firm is to maximise an expected profit, but since the only stochastic variable in the model is the exchange rate, the model is written without the expectation operator. $x($.$) is an import demand, which is a function of the price of imported product$ $(p)$, the price of a competing variety $(q)$, and income level $(I)$, all of which is denoted in the unit of domestic currency. $c($.$) is the cost function, which depends on the foreign factor$ price and quantity demanded, and is denoted in the unit of foreign currency.

The formulation shows that the change in expected exchange rate or tariff rate can be represented as a cost shifter. To the extent that the changes in tariff and exchange rate affect the term $(1+\tau) / e$ equivalently, the pricing decision does not depend on the source of cost shocks. Thus, the model predicts a symmetry of ERPT and TRPT.

The symmetry hypothesis, however, requires assumptions that may not be tenable in various practical settings. If production costs co-vary with exchange rate (Goldberg and Hellerstein, 2008), which can happen when inputs include imported materials, the symmetry prediction does not hold. Similar to the concern discussed by Marion and Muehlegger (2008) in the context of local diesel markets, the transition effects of tariffs and exchange rates are unlikely to be the identical since tariff change may be fully expected while the 
exchange rate movements are much uncertain. If the fluctuation of exchange rate is small and the producers do not make any adjustment to small changes in exchange rate due to menu costs, the degree of ERPT may underestimate the degree to which the producer respond to a large change in tariff. Despite these theoretical concerns, previous empirical studies find that the degree of ERPT and TRPT are not different statistically (Feenstra, 1989; Winkleman and Winkleman 1998). ${ }^{21}$ Thus, ERPT provides a first approximation of the expected response of prices in absence of tariff evasion.

\section{What is a sensible range for a TRPT coefficient?}

Table 3 provides a summary of previous ERPT studies on various food categories in Japan.

\section{Table 3: ERPT estimates from closely related commodities}

\begin{tabular}{lllll}
\hline \multicolumn{1}{c}{ Study } & Category & $\begin{array}{l}\text { Estimation } \\
\text { Period }\end{array}$ & ERPT & $\begin{array}{l}\text { Import } \\
\text { share (year) }\end{array}$ \\
\hline [1] Kimura et al. (1997) & $\begin{array}{l}\text { Livestock } \\
\text { products }\end{array}$ & $1985-1994$ & 0.707 & $0.20(1990)$ \\
[2] Campa \& Goldberg (2005) & Food & $1975-2003$ & 0.269 & - \\
[3] Ohtani et al. (2003) & Food & $1991.1-2002.10$ & 0.59 & - \\
[4] Miljkovic \& Zhuang (2007) & Beef & $1996.11-2006.1$ & 0.504 & $0.58(2005)$ \\
& Pork & $1996.11-2006.1$ & 0.129 & $0.53(2005)$ \\
& Poultry & $1996.11-2006.1$ & 0.943 & $0.40(2005)$ \\
[5] Ono (2007) & Frozen minced 2001.1-2007.6 & 0.657 & $0.64(2002)$ \\
& Alaskan Pollack & & \\
\hline & imported from US & & \\
\hline
\end{tabular}

Notes: The frequency for the data is monthly except [1] (two periods) and [2] (quarterly). Data is import price indices, at varying level of disaggregation, published by the Bank of Japan except [1] (input-output table) and [4] (trade statistics).

Source: Author's Calculations

Overall, the ERPT estimates range from 0.129 to 0.94. Campa and Goldberg (2005) provide a low estimate (0.269) based on quarterly data on the Japanese food price index on import. Ohtani et al. (2003) replicate the Campa-Goldberg study with monthly data and find a larger coefficient (0.59). In an early study, Kimura et al. (1997) use the import price deflator for livestock products - more relevant food category — and report the estimate of 0.71. Miljkovic and Zhuang (2007) focus on even narrower categories: beef, pork, and poultry. The data source, however, is the Japanese trade statistics, where declared values for pork are highly susceptible to misreporting. Possibly reflecting the misreporting concern, the estimated ERPT coefficient for pork is the lowest among all estimates $(0.129)$ and is not significantly different from zero. The estimate for beef and 
poultry is 0.50 and 0.94 respectively. Ohno (2007) focuses on the price of minced frozen Alaska Pollack, and finds an ERPT estimate of 0.66. Like frozen pork, this frozen fish product is mainly processed to produce traditional fish cakes. From the comparability of the data frequency and product category, I take a range of $0.5-0.7$ as a benchmark for a TRPT into the pork price.

\section{Panel data analysis}

To address the issue with power, I utilise the panel data on pork-parts price series. I have considered the validity of a group of high-value parts as a control sample. I define lowvalue parts to include all frozen parts except tenderloin (that is backribs, belly, butt, collar) and high-value parts to include all the chilled meats (backribs, belly, butt, loin, tenderloin) and frozen tenderloin. The mean price for the former and latter group is $\mathbf{5 7 9}$ and 793 yen/kilo respectively. Given that the average price of the former is well below the price floor under SG, the direct impacts of SG are expected to fall on low-value meats. Initial examination revealed that a group of chilled products would not serve as an appropriate control products for a group of frozen products since the price of chilled parts appear to be influenced more by the outbreaks of livestock diseases, such as the bird flu outbreaks in 2001-2002, and the BSE concerns for domestic as well as US beef. ${ }^{22}$ These factors might have increased the price volatility since chilled meats are consumed directly. The possible change in the seasonal pattern for high-value meat raises a question about the appropriateness of using the group as a control in implementing a difference-in-difference analysis. Thus, I consider a difference estimator in this paper.

The data is the unbalanced panel of JMTC pork price series for a category of lowvalue parts described above. Exchange rates variables, in addition to the price series, are found to contain unit roots. Given the concern about the panel spurious regression when the cross-section dimension is small, I estimate the model in first difference. The following is a difference model estimated in the sample of low-value parts.

$$
\Delta \ln p_{i t}=\alpha_{0}+\sum_{m=1}^{3} \alpha_{k m} \Delta \ln e_{k, t-m}+\sum_{j=1}^{12} \lambda_{j} s g_{j t}+X_{i t}^{\prime} \theta+u_{i t}
$$

$p_{i t}$ is the price of $i^{\text {th }}$ commodity in log. There are 15 series, containing 3 origin countries, 2 storage types, 5 parts, and 3 locations at the destination country. $e_{k, t-m}$ is the $m^{\text {th }}$ lag of the exchange rate between yen and the origin country currency in log. I follow the ERPT literature and use the spot market data. $\alpha_{k, t-m}$ is a currency-specific ERPT coefficient, assumed to be constant across commodities from a same origin country $(k)$. The specification includes three lags.

To flexibly model the impacts of SG invocations and removals, a preferred specifica- 
tion includes dummy variables $\left(s_{j}\right)$ indicating $j^{\text {th }}$ month in a fiscal year since the invocation of each SG in JFY 2001, 02, 03 and 04. for example $s g_{1, t}$ and $s g_{12, t}$ is, respectively, a dummy variable for August 2001-04 and July 2002-05. $\lambda_{j}$ is the main coefficient of interest, and is designed to capture the difference in price changes across months with and without $S G$. We would expect that a cumulative value of $\lambda$ to be positive when SG has had its intended effects of increasing the price of imported pork. Under the assumption that the seasonal trend remains the same on average, the coefficient is interpreted as the impact of the SG. The models are estimated with OLS with standard error clustered by each series.

$X_{i t}$ is a vector of control variables: seasonality controls that allow for heterogeneous trend for 6 parts stored in different methods; year-country specific production cost control; dummies for April 2005, the month just after the enactment of the strengthened penalty, and two lags.

\section{Results}

Table 4 presents the analysis, progressively adding control variables. For the sample of low-value commodities, the coefficients on the SG dummies are generally not significantly different from zero, and are sensitive to the addition of controls for those that have significant coefficients in the baseline specification, which only control for parts-storage specific seasonality (Column 1). A test on joint significance, to be discussed below, confirms the lack of explanatory power of the SG on price. The exchange rates appear to have a weak explanatory power in the sample of frozen commodities. In the full specification (Column4), the individual coefficients are not significant, except for the first lag of Canadian dollar (CAD). The sum of the coefficients are 0.125, 0.076, and 0.097 for CAD, Denmark Kroner (DKK), and US dollar (USD), respectively. Jointly, USD is significant but not CAD and DKK. The timing of the enactment of the tougher penalty law is strongly correlated with the price increase. The first and second lags are significant at the 5 and 1 per cent level respectively. The three penalty law variables are jointly significant at the 1 per cent level. 
No. 382,2009

Table 4: The estimate of a difference model using low-value pork parts sample

\begin{tabular}{|c|c|c|c|c|}
\hline & {$[1]$} & [2] & [3] & {$[4]$} \\
\hline sg_aug & $\begin{array}{c}-0.0088 \\
(0.0110)\end{array}$ & $\begin{array}{c}-0.0084 \\
(0.0109)\end{array}$ & $\begin{array}{c}0.0028 \\
(0.0159)\end{array}$ & $\begin{array}{l}-0.0113 \\
(0.0174)\end{array}$ \\
\hline sg_sep & $\begin{array}{l}-0.0037 \\
(0.0066)\end{array}$ & $\begin{array}{l}-0.0039 \\
(0.0075)\end{array}$ & $\begin{array}{c}0.0075 \\
(0.0081)\end{array}$ & $\begin{array}{c}-0.0043 \\
(0.0088)\end{array}$ \\
\hline sg_oct & $\begin{array}{c}0.0006 \\
(0.0072)\end{array}$ & $\begin{array}{c}0.0010 \\
(0.0081)\end{array}$ & $\begin{array}{c}0.0126 \\
(0.0147)\end{array}$ & $\begin{array}{c}0.0014 \\
(0.0167)\end{array}$ \\
\hline sg_nov & $\begin{array}{c}0.0078 \\
(0.0052)\end{array}$ & $\begin{array}{c}0.0078 \\
(0.0053)\end{array}$ & $\begin{array}{l}0.0197^{*} \\
(0.0074)\end{array}$ & $\begin{array}{c}0.0076 \\
(0.0084)\end{array}$ \\
\hline sg_dec & $\begin{array}{l}-0.0112^{*} \\
(0.0041)\end{array}$ & $\begin{array}{l}-0.0115^{*} \\
(0.0046)\end{array}$ & $\begin{array}{c}-0.0002 \\
(0.0085)\end{array}$ & $\begin{array}{c}-0.0128 \\
(0.0114)\end{array}$ \\
\hline sg_jan & $\begin{array}{c}0.0020 \\
(0.0081)\end{array}$ & $\begin{array}{c}0.0025 \\
(0.0083)\end{array}$ & $\begin{array}{c}0.0131 \\
(0.0098)\end{array}$ & $\begin{array}{c}0.0083 \\
(0.0094)\end{array}$ \\
\hline sg_feb & $\begin{array}{c}-0.0338^{* *} \\
(0.0074)\end{array}$ & $\begin{array}{c}-0.0212^{*} \\
(0.0076)\end{array}$ & $\begin{array}{c}-0.0101 \\
(0.0133)\end{array}$ & $\begin{array}{c}-0.0166 \\
(0.0142)\end{array}$ \\
\hline sg_mar & $\begin{array}{c}-0.0179^{* *} \\
(0.0054)\end{array}$ & $\begin{array}{c}-0.0106^{*} \\
(0.0042)\end{array}$ & $\begin{array}{c}-0.0002 \\
(0.0094)\end{array}$ & $\begin{array}{c}-0.0134 \\
(0.0142)\end{array}$ \\
\hline sg_apr & $\begin{array}{c}0.0073 \\
(0.0056)\end{array}$ & $\begin{array}{c}-0.0013 \\
(0.0047)\end{array}$ & $\begin{array}{c}0.0097 \\
(0.0088)\end{array}$ & $\begin{array}{l}-0.0061 \\
(0.0126)\end{array}$ \\
\hline sg_may & $\begin{array}{c}0.0219^{* *} \\
(0.0072)\end{array}$ & $\begin{array}{l}0.0238^{*} \\
(0.0086)\end{array}$ & $\begin{array}{l}0.0331^{*} \\
(0.0134)\end{array}$ & $\begin{array}{r}0.0036 \\
(0.0136)\end{array}$ \\
\hline sg_jun & $\begin{array}{c}0.0071 \\
(0.0056)\end{array}$ & $\begin{array}{c}0.0059 \\
(0.0058)\end{array}$ & $\begin{array}{c}0.0154 \\
(0.0108)\end{array}$ & $\begin{array}{l}0.0115 \\
(0.0115)\end{array}$ \\
\hline sg_jul & $\begin{array}{c}0.0062 \\
(0.0084)\end{array}$ & $\begin{array}{c}0.0059 \\
(0.0083)\end{array}$ & $\begin{array}{c}0.0070 \\
(0.0081)\end{array}$ & $\begin{array}{r}0.0100 \\
(0.0082)\end{array}$ \\
\hline $\mathrm{Ll}(\mathrm{CAD})$ & & $\begin{array}{c}0.0186 \\
(0.0154)\end{array}$ & $\begin{array}{l}0.0353+ \\
(0.0200)\end{array}$ & $\begin{array}{l}0.0639^{*} \\
(0.0237)\end{array}$ \\
\hline $\mathrm{L} 2(\mathrm{CAD})$ & & $\begin{array}{c}0.0304 \\
(0.0593)\end{array}$ & $\begin{array}{l}0.0611 \\
(0.0703)\end{array}$ & $\begin{array}{r}0.0915 \\
(0.0717\end{array}$ \\
\hline $\mathrm{L} 3(\mathrm{CAD})$ & & $\begin{array}{c}-0.0288 \\
(0.0306)\end{array}$ & $\begin{array}{c}-0.0045 \\
(0.0369)\end{array}$ & $\begin{array}{l}-0.0301 \\
(0.0351)\end{array}$ \\
\hline $\mathrm{Ll}(\mathrm{DKK})$ & & $\begin{array}{c}-0.0532 \\
(0.0678)\end{array}$ & $\begin{array}{c}-0.0384 \\
(0.0758)\end{array}$ & $\begin{array}{c}0.0390 \\
(0.0901)\end{array}$ \\
\hline L2(DKK) & & $\begin{array}{c}-0.0044 \\
(0.0702)\end{array}$ & $\begin{array}{c}0.0078 \\
(0.0781)\end{array}$ & $\begin{array}{c}0.0379 \\
(0.0940)\end{array}$ \\
\hline L3(DKK) & & $\begin{array}{c}0.0274 \\
(0.0511)\end{array}$ & $\begin{array}{c}0.0238 \\
(0.0535)\end{array}$ & $\begin{array}{l}-0.0005 \\
(0.0595)\end{array}$ \\
\hline $\mathrm{Ll}(\mathrm{USD})$ & & $\begin{array}{c}-0.0414 \\
(0.0873)\end{array}$ & $\begin{array}{c}-0.0518 \\
(0.1120)\end{array}$ & $\begin{array}{c}-0.0411 \\
(0.0990)\end{array}$ \\
\hline L2(USD) & & $\begin{array}{c}-0.0122 \\
(0.1338)\end{array}$ & $\begin{array}{c}0.0129 \\
(0.1275)\end{array}$ & $\begin{array}{c}0.0443 \\
(0.1396)\end{array}$ \\
\hline L3(USD) & & $\begin{array}{l}0.1215^{*} \\
(0.0513)\end{array}$ & $\begin{array}{c}0.1547^{*} \\
(0.0593)\end{array}$ & $\begin{array}{c}0.0941 \\
(0.0666)\end{array}$ \\
\hline Penalty Law & & & & $\begin{array}{c}0.0224 \\
(0.0192)\end{array}$ \\
\hline Ll(Penalty Law) & & & & $\begin{array}{c}0.0365^{*} \\
(0.0147)\end{array}$ \\
\hline L2(Penalty Law) & & & & $\begin{array}{c}0.0802^{* *} \\
(0.0199)\end{array}$ \\
\hline $\begin{array}{l}\text { SEASONALITY } \\
\text { ORIGIN SPECIFIC COSTS }\end{array}$ & $\begin{array}{l}\text { YES } \\
\text { NO }\end{array}$ & $\begin{array}{l}\text { YES } \\
\text { NO }\end{array}$ & $\begin{array}{l}\text { YES } \\
\text { YES }\end{array}$ & $\begin{array}{l}\text { YES } \\
\text { YES }\end{array}$ \\
\hline Constant & $\begin{array}{l}0.0114^{* *} \\
(0.0000)\end{array}$ & $\begin{array}{l}-0.0031 \\
(0.0101)\end{array}$ & $\begin{array}{l}-0.0015 \\
(0.0079)\end{array}$ & $\begin{array}{c}0.0032 \\
(0.0081)\end{array}$ \\
\hline Observations & 1008 & 963 & 963 & 963 \\
\hline Adjusted R-squared & 0.03 & 0.02 & 0.04 & 0.08 \\
\hline
\end{tabular}

Notes: Robust standard errors, clustered by each series, are in parentheses. + significant at $10 \%$;

* significant at $5 \%$; ** significant at $1 \%$. Variables except dummies are differenced.

Source: Author's Calculations 
To interpret these estimates, the SG did not resulted in an average increase of prices of low-value commodities relative to the same set of commodities in the period when SG was not in place. The difference estimate allows for unobserved country-specific cost shocks. The exchange rates in general appear to have a weak explanatory power for pork products in this sample. In a descriptive industry study, Kaku and Fukase (2002) argue that the fluctuation of exchange rates are fully borne by sellers since the convention in the pork export to Japan, which adopts the variable levy, is to invoice in yen. While a strong proposition that is supported by the estimates only partially, it is possible that ERPT coefficient estimated here might underestimate the degree of TRPT for this reason. Additionally, to the extent that the traders adjust abnormal profit earned from evasion, ERPT would be attenuated. To be sure, under the assumption of zero TRPT coefficients, the hypothesis of tariff evasion is not distinguishable from the alternative hypothesis of a full incomplete pass-through of tariff in an empirical strategy solely based on variations in market prices to identify evasion. I thus proceed by using the range of previous ERPT estimates discussed above. Finally, the strengthening of enforcement seems to have had an impact. The enforcement includes prosecutions of larger criminal cases, increased penalty, and nudging firms not to evade, and the effects of these different policy tools are combined in the estimate. The effects of the nudging may seem controversial given that there seem to be no real incentives to act, and indeed, one politician raised concern about its effectiveness. ${ }^{23}$ However, warning taxpayers have been shown to affect behaviour in randomised studies (Slemrod, Blumenthalb and Christianc, 2001). One may be concerned that the fuel and other production costs increased during the mid-2000s might have confounded the influence of the penalty variables, but the year-country specific dummies should capture those confounding effects.

Table 5 shows the Wald tests that compare the sum of safeguard coefficients to the product of the presumed pass-through coefficient and the change in the average declared price in $\log [0.22=\ln (681.08-546.53)]$. The coefficients used in the tests are based on the difference estimate from the full specification (Column 4). In one extreme, under the assumption that the full burden of tariff increase is passed onto buyers, we should observe a change of 0.22 in log price level. The test rejects the null of no evasion under the full pass-through assumption at the 1 per cent level. In the other extreme, if we assume instead that a TRPT coefficient to be low, say 12.9 per cent, the lowest estimates of ERPT from the studies reviewed above, the sum of the estimates are not distinguishable from an increase of 0.066 in log price level, leading us to accept the maintained hypothesis that there was no evasion. For a realistic range of TRPT (50-70 per cent), the tests reject the null at the 5 or 10 levels. The result of the test naturally depends on the presumed parameter value. However, for a sensible parameter range, the test rejects the hypothesis that the lack of 
price response was due to the pricing behaviour of traders. ${ }^{24}$

Table 5:The test for the null of no evasion

\begin{tabular}{ccc}
\hline Tariff-rate pass-through coefficients $(\%)$ & Wald statistic & \\
\hline 100 & 9.46 & $*$ \\
80 & 6.54 & $*$ \\
70 & 5.28 & + \\
60 & 4.30 & + \\
50 & 3.17 & \\
40 & 2.31 &
\end{tabular}

Notes: The results from the Wald tests. + significant at $10 \%$; * significant at $5 \%$; ** significant at $1 \%$.

Source: Author's Calculations

To check the finding, Figure 4 presents the prices of low-value pork parts before and after March 2005, when the last safeguard was removed. The figures plot the percentage deviation of average monthly price from the respective group average. The series on the pattern after March 2005 (dotted lines) should capture seasonal trend. If SG has had any effects we would expect to see a deviation from the seasonality in the normal years, especially over August-March. Two lines are nearly identical, except for the deviation in January-February and June-July.

\section{Figure 4: Percentage of deviation of monthly prices}

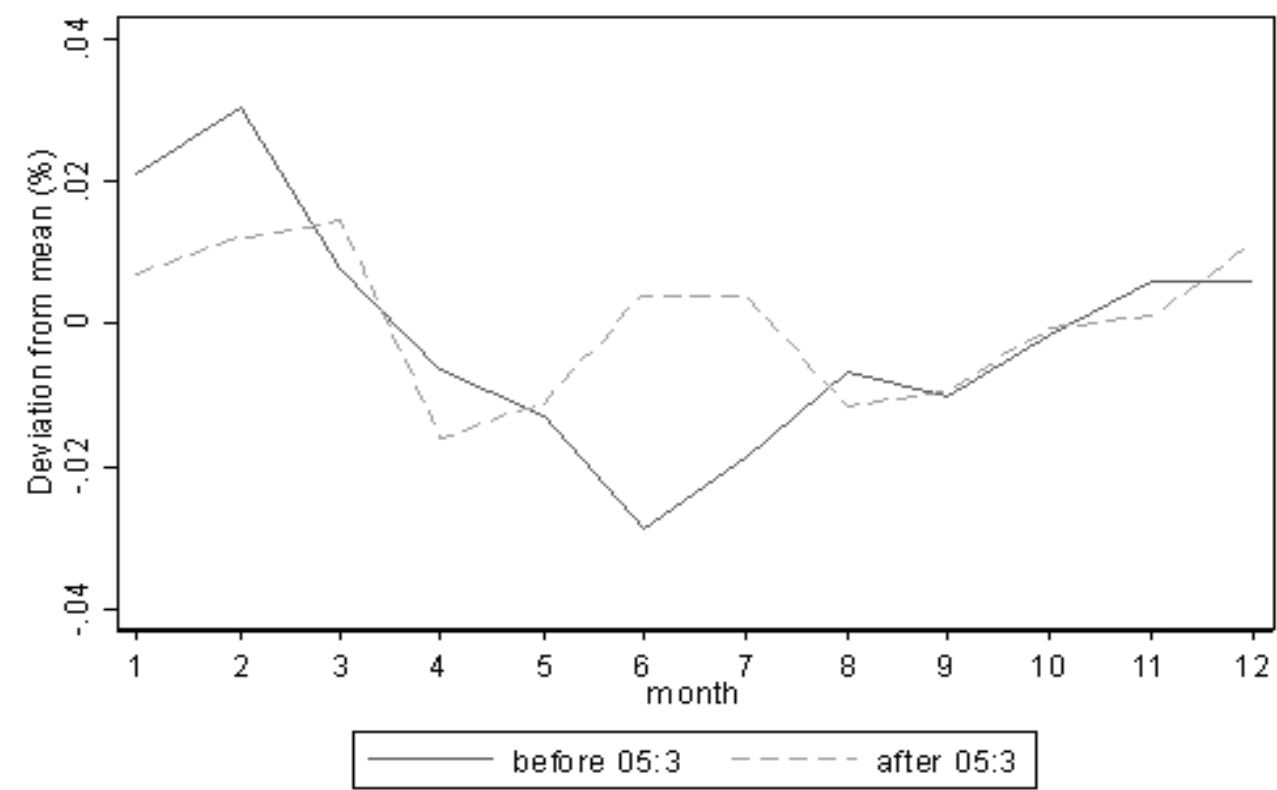

Source: Author's Caculations 


\section{Other explanations}

\section{Was the attenuation due to boarding?}

The price would not have respond as much if traders were able to stockpile when the tariff was low and to sell them off when the tariff was high. While traders incur storage costs and forgo interest earnings, frozen pork is physically storable. Figure 5 plots the fraction of frozen pork imported to Japan over August-March from JFY1988 through 2007 using the Japanese trade statistics. The hoarding behaviour would imply increases in the share of imports in April-July so that we would expect to observe reductions in the August-March import share over JFY2001-2004. The most salient pattern in the figure is the reduction of the share in JFY1996, which is attributable to the invocation of a SSG that increased the tariff rate on top of the increased price floor over January through March 1997. The pattern suggests that importers adjusted the real timing of import in JFY1996. Over JFY20012004 , in contrast, substantial fractions of pork clear custom when tariff is high, indicating that SG did not cause shift in timing as much as in JFY1996. Thus, hoarding would not have had a first-order effect on the price level of frozen pork during SG in the 2000s.

Figure 5: The share of imports over August-March

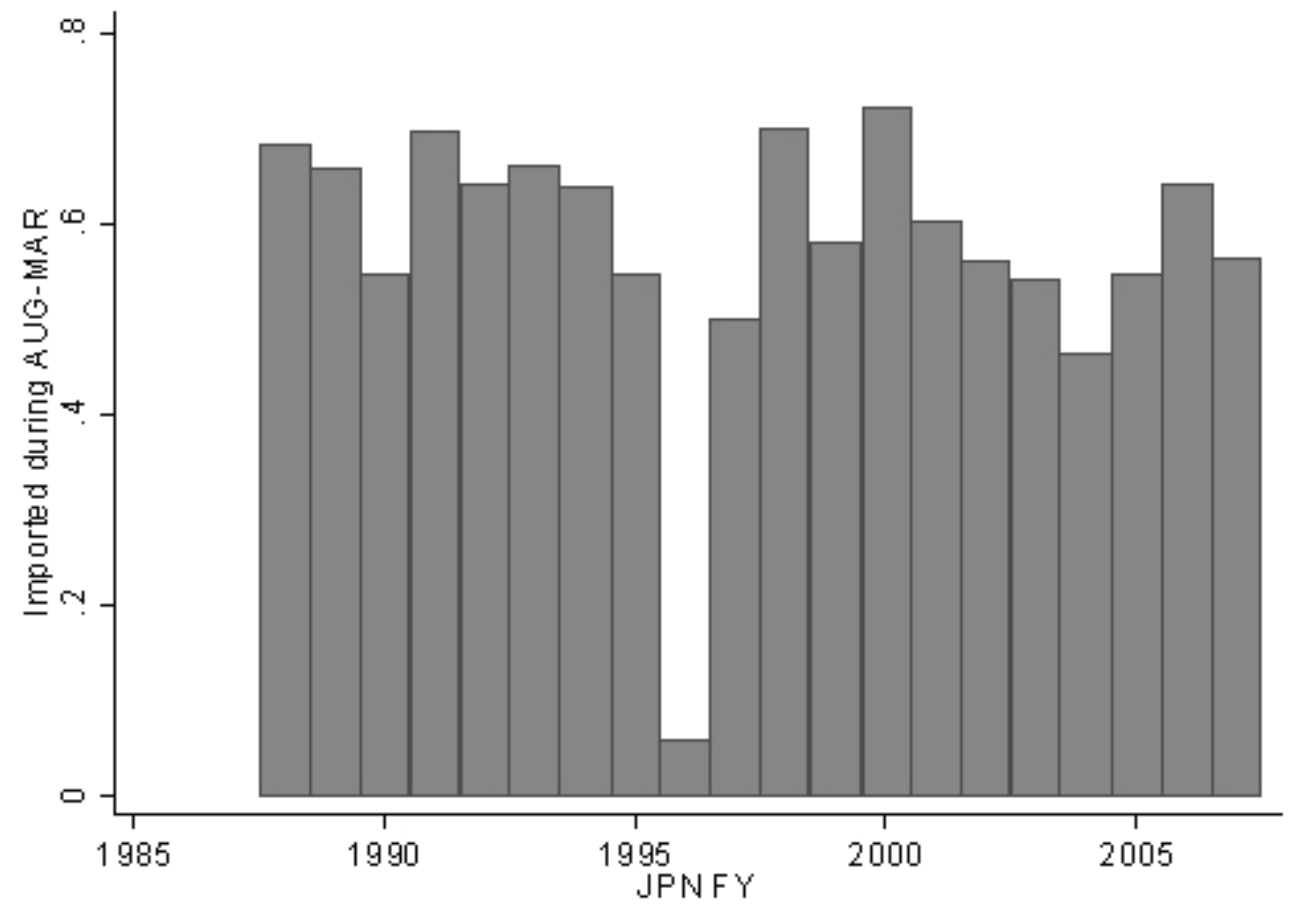

Source: Author's Caculations 


\section{Was the attenuation due to tax avoidance?}

Another alternative explanation for the lack of price response to safeguards is the tax avoidance through the mixing of parts. By increasing the average price on invoice through increasing the share of high-value meats, importers can avoid paying penalising tariff applicable to pork imported at prices below the gate price. While this strategy increases costs to traders due to the purchase of high-value parts that would not have been imported otherwise, the full burden of the safeguard would not be borne by market participants.

Figure 6 plots the value of frozen pork per kilo exported to Japan declared at the Denmark custom (solid line). If there was a change in the composition of pork parts exported from Denmark, the average value should increase, perhaps with a lead. The data is based on frozen pork category that corresponds to the Japanese custom data. The dotted line shows the frozen pork parts imported from Denmark reported to the Japanese custom. Put differently, the figure presents a time series examination of the price gap in the context of frozen port import into Japan to be discussed below.

\section{Figure 6: The price gap analysis}

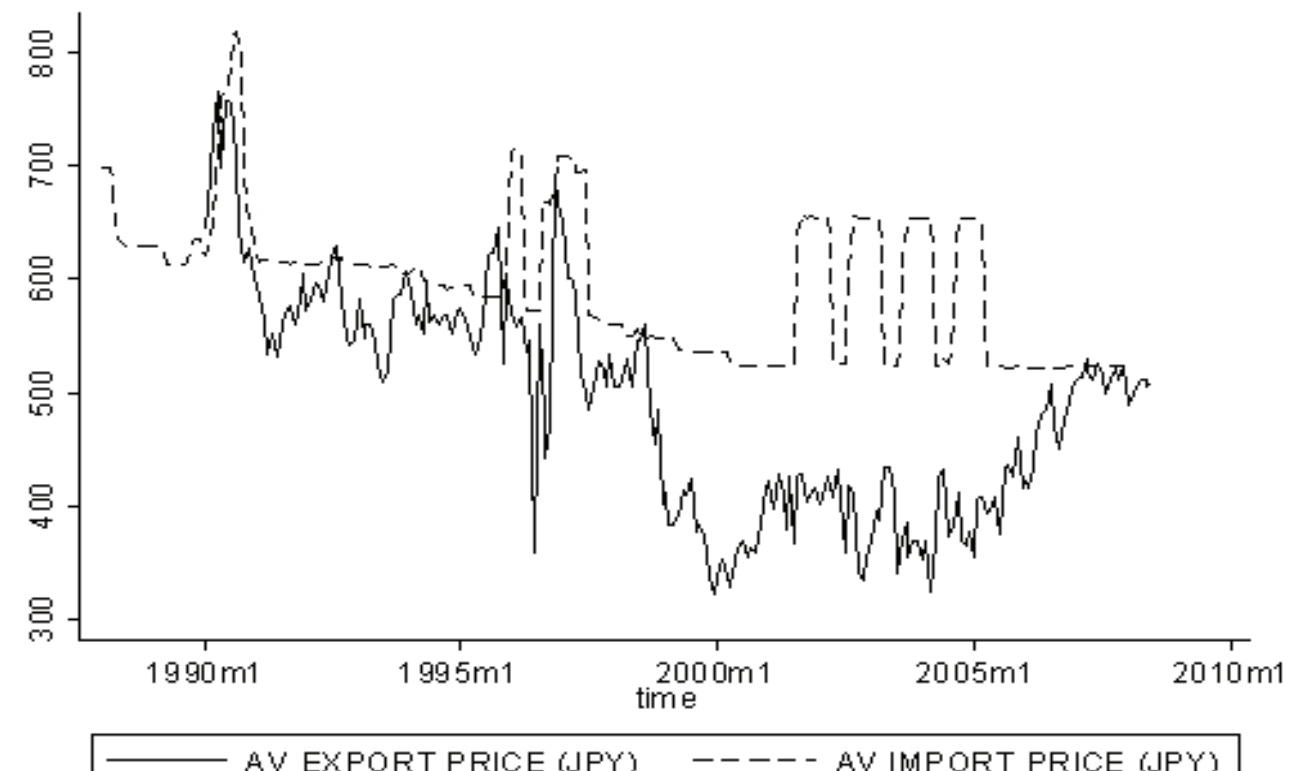

Source: Author's Caculations

For 2001-2004, the volatility of the value declared at Denmark appears to increase, perhaps reflecting some adjustments in the timing of trade. However, there seems no significant indication that the mixing strategy was in wide use. Tanaka and Mori (2001) find the mixing strategy to be significant but their study is based on chilled US products in 1998-2000. It is thus unlikely that the mixing strategy explain the lack of price response in the 2000s for the Denmark frozen pork. 


\section{Alternative approach: Price-gap estimate of evaded duties}

The most salient feature of Figure 6 is the gap between prices over 1999-2005. Two lines are reasonably close in other periods; the 1996 safeguard is associated with a sharp temporary rise in the average value declared at Denmark, indicating that much of the imports for the period employed the tax avoidance strategy - a pattern that is in line with the sharp reduction in the imported volume during SG and SSG noted above. In contrast, from the late 1990s to the mid-2000s, the declared values at Denmark are visibly below those declared at Japan. The behaviour of price gaps is thus consistent with the lack of price response to SG documented above.

The broad pattern is in line with the market development. As the share of import in the domestic pork consumption increased during the 1990s, the detection probability would have fallen, all else equal. A larger market size would be conducive to evasion since the evasion production function is likely to exhibit economies of scale; court cases have documented elaborate evasion schemes that involve establishments of shell companies, indicating that firms need to invest in learning evasion strategy. ${ }^{25}$ The closing of the price gap starting in 2005 can be explained by the strengthening of law enforcement. Recall from the above analysis that the price of low-value parts increased at the time that the enforcement was strengthened. Compliance to the tariff regime would have resulted in traders resorting to the mixing strategy, which increases costs of imports.

Table 6 shows the price-gap estimate of evaded custom duties on the Japanese import of Denmark frozen pork parts. The price gap is defined as the difference between the CIF (per kilo) declared at the Japanese custom and the one-month lag of FOB (per kilo) declared at the Denmark custom. The lag of one month is chosen because shipping from Copenhagen to Yokohama takes 36 days. ${ }^{26}$ The Danish Krone in the Denmark data is converted to Yen using spot exchange rates. The evasion estimate is the product of the price gap and corresponding volume declared at the Japanese custom. The estimate is intended to provide an upper bound estimate only: once again, the sources of discrepancy include the costs of transportation (fright, insurance, other expenses), the difference in the timing of import and export, actual exchange rate used by trading parties, and commodities damaged during transport. However, since those sources of disparities are unlikely to change abruptly, the price gap estimates would provide a reasonable comparison across time. 
Table 6: Revenue and Evasion: Denmark Frozen Pork

\begin{tabular}{|c|c|c|c|c|c|c|}
\hline \multicolumn{3}{|c|}{ Evasion Estimate } & Revenue & \multicolumn{3}{|c|}{ Evasion-Revenue Ratio } \\
\hline JFY & All year & Safeguard & All year & Safeguard & All year & Safeguard \\
\hline & Apr.-Mar. & Aug.-Mar. & Apr.-Mar. & Aug.-Mar. & Apr.-Mar. & Aug.-Mar. \\
\hline 1998 & $9,006.0$ & - & $3,598.4$ & - & 2.50 & - \\
\hline 1999 & $34,134.5$ & - & $4,946.0$ & - & 6.90 & - \\
\hline 2000 & $29,849.1$ & - & $4,417.1$ & - & 6.76 & - \\
\hline 2001 & $40,668.1$ & $31,357.3$ & $5,677.1$ & $3,727.2$ & 7.16 & 8.41 \\
\hline 2002 & $46,078.6$ & $34,496.8$ & $5,674.9$ & $3,463.0$ & 8.12 & 9.96 \\
\hline 2003 & $47,623.3$ & $35,752.5$ & $5,945.6$ & $3,520.2$ & 8.01 & 10.16 \\
\hline 2004 & $53,161.3$ & $32,700.8$ & $6,647.7$ & $3,424.8$ & 8.00 & 9.55 \\
\hline 2005 & $24,837.4$ & - & $5,297.9$ & - & 4.69 & - \\
\hline 2006 & $6,853.7$ & - & $3,898.7$ & - & 1.76 & - \\
\hline 2007 & 834.3 & - & $2,709.8$ & - & 0.31 & - \\
\hline Total & $293,046.3$ & $134,307.4$ & $48,812.9$ & $14,135.2$ & 6.00 & 9.50 \\
\hline
\end{tabular}

Notes: The unit is in million yen.

Source: Author's Calculations

Over the decade spanning JFY1998-2007, the upper-bound estimate of total evasion on Denmark frozen pork is 293 billion yen. The amount is 6 times as large as the total tariff revenue on the commodity from Denmark. The evasion-revenue ratio shows a substantial time variation, peaking at 8.12 in 2002, and falling to 0.31 in 2007 . This pattern suggests an evasion epidemic over 1999-2005, followed by a period of better compliance. The ratio during the safeguard in JFY2001-04 is higher because of the larger amount of tariff evaded per kilo due to the higher price floor. A higher evasion-revenue ratio during the safeguard period indicates that the tariff revenue from Denmark pork did not respond as much to the increase in tariff due to evasion. In sum, this auxiliary evidence supports the interpretation that the price disparity as due to tariff evasion rather than the adjustment of profit margins. Further, evidence supports the interpretation that the break in cointegrating relationship between Denmark frozen belly and tenderloin as due to the better compliance to the variable tariff levy.

\section{Concluding remarks}

This paper examined the disparities between the observed prices of low-value imported pork parts and the predicted prices that would have prevailed under the full compliance to the increases in a price floor under the Japanese variable levy on pork. Statistically significant disparities between prices were found during the safeguard tariff of JFY20012004, and were best explained by tariff evasion. A complementary examination based on a comparison of trade statistics from Japan and Denmark — the leading exporter of frozen 
pork to Japan — revealed visible gaps over JFY1999-2005, indicating an epidemic of under-invoicing to reduce tax liability. Alternative explanations for the lack of price response were considered but were unlikely to account for the divergence of market prices from the theoretical benchmark. The results indicated that the strengthening of enforcement have had a statistically significant impact on price. I estimated the total amount of tariff evaded on Denmark frozen pork to be 293 billion yen over 1998-2007. This amount was 6 times as much as the revenue collected from those commodities in the period.

The analysis has implications beyond the current context. First, in line with Cooper (1974) and Pitt (1981a,b), this study shows that price disparities give indications about the presence of pervasive tax evasion. Particularly, a comparison of two similar commodities that are reasonably thought of as differentially affected by non-compliance would provide a quick visual check. Second, the results raise questions about the effectiveness of safeguard tariffs as a public policy tool. Safeguard tariffs affect the margins of incentives that are neglected in the partial equilibrium analysis of a commodity tax. A tax hike increases the incentives for misreporting (Fisman and Wei, 2005), and I find a near complete attenuation of safeguard tariff in the current setting. Thus, to achieve its protectionist goal, safeguard tariffs should be accompanied by a closer monitoring by Customs. However, policy makers should be aware that such efforts draw resource away from the monitoring of other imported commodities or even border protection when the custom resource is fixed.

Several extensions to this paper are possible. First, it would be of interest to examine price disparities in countries that rely more heavily on tariff as a revenue source. Particularly, it seem a useful exercise to see whether price disparities exist for commodities that are found to have price gaps in China, India and Eastern Europe (Fisman and Wei 2005; Mishra, Subramanian, and Topalova, 2008; Javorcik and Narciso, 2008). Conversely, studies have suggested the lack of price response to the US steel safeguard of 2002 (Liebman, 2006). The pattern might have been caused by exemptions granted to a number of source countries, but since the press reports widespread smuggling in US steel imports, ${ }^{27}$ an interesting question would be: Are there price gaps for the steel imports into the United States? Last, given the goal of protecting Japanese pork producers, a further study might ask to what extent the Japanese pork safeguard was successful in maintaining the prices of domestic pork. 


\section{References}

Alm, J., Sennoga, E., and Skidmore, M., 2009. 'Perfect Competition, Urbanization, and Tax Incidence in the Retail Gasoline Market', Economic Inquiry 47:118-34.

Andreoni, J., Erard, B., and Feinstein, J., 1998. 'Tax Compliance', Journal of Economic Literature 36:818-60.

Besley, T.J., and Rosen, H.S., 1999. 'Sales Taxes and Prices: An Empirical Analysis', National Tax Journal 52:157-176.

Bhagwati, J., 1964. 'On the Under-invoicing of Imports', Bulletin of the Oxford University Institute of Statistics 26:389-97.

Bhagwati, J., 1974. Illegal Transactions in International Trade: Theory and Measurement, NorthHolland Publishing Company, Amsterdam.

Bhagwati, J., and Hansen, B., 1973. 'A Theoretical Analysis of Smuggling', Quarterly Journal of Economics 87:172-187.

Baunsgaard, T., and Keen, M., 2005. 'Tax Revenue and (or?) Trade Liberalization', International Monetary Fund Working Paper 05/112.

Campa, J.M., and Goldberg, L.S., 2005. 'Exchange rate pass-through into import prices', Review of Economics and Statistics 87:679-690.

Cabinet Office, Japan. 2007. Economic and Fiscal Reform 2007. Cabinet Office, Tokyo. (available from http://www.keizai-shimon.go.jp/explain/2007link/basic_policies2007.pdf, downloaded March 31, 2008.)

Chetty, R., Looney, A., and Kroft, K., 2007. 'Salience and taxation: Theory and evidence', NBER Working Paper Series No. 13330.

Cooper, R.N., 1974. 'Tariffs and smuggling in Indonesia', in Bhagwati, J. (ed) Illegal Transactions in International Trade: Theory and Measurement, North-Holland Publishing Company, Amsterdam, 183-192.

von Cramon-Taubadel, S., 1997. 'Estimating asymmetric price transmission with the error correction representation: An application to the German pork market', European Review of Agricultural Economics 25:1-18.

Feenstra, R.C., 1989. 'Symmetric pass-through of tariffs and exchange rates under imperfect competition: An empirical test', Journal of International Economics 27:25-45.

— 1995. 'Estimating the effects of trade policy', in Grossman G.M. and Rogoff K. (eds.) Handbook of International Economics, Elsevier, Amsterdam, 1553-1595.

Fisman, R., and Wei, S.J., 2004. 'Tax Rates and Tax Evasion: Evidence from Missing Imports in China', Journal of Political Economy 112:471-496.

Goldberg, P.K., and Hellerstein, R., 2008. 'A structural approach to explaining incomplete exchange-rate pass-through and pricing-to-market', American Economic Review: Papers and Proceedings 98:423-429.

Gordon, R.H., and Hines, J.R. Jr., 2002. 'International Taxation', in: Auerbach AJ \& Feldstein M (eds.) Handbook of Public Economics, Elsevier, Amsterdam, 1935-1995.

Gordon, R.H., and Slemrod, J., 2000. 'Are real responses to taxes simply income shifting between corporate and personal tax base?'. in Slemrod J. (ed.) Does Atlas Shrug? The Economic Consequences of Taxing the Rich. Harvard University Press, MA, 240-328.

Harris, S., Swinbank, A., and Wilkinson, G., 1983. The Food and Farm Policies of the European Community. John Wiley \& Sons, New York.

Hayashi, F., 2000. Econometrics. Princeton University Press, Princeton.

Hummels, D.L., and Lugovskyy, V., 2006. 'Are Matched Partner Trade Statistics a Usable Measure of Transportation Costs?’. Review of International Economics 14:69-86. 
Javorcik, B.S., and Narciso, G., 2008. 'Differentiated products and evasion of import tariffs', Journal of International Economics 76:208-222.

Kaku, K., and Fukase, M., 2002. 'Production, Distribution, Consumption and Price Formation of Pork in Japan: Basic Research for the Pork Futures Market'. Futures Market Research 1:1-62 (in Japanese).

Kimura, H., Suzuki, H., Saito, T., Suzuki, T., Shimada, H., and Murota, H., 1997. 'Economic Effects of Yen Appreciation: A Sectoral Approach', Keizai Bunseki (Economic Analysis) 148:1-53 (in Japanese).

Liebman, B.H., 2006. 'Safeguards, China, and the Price of Steel', Review of World Economies 142:354-373.

Lovely, M.E., 1994. 'Crossing the Border: Does Commodity Tax Evasion Reduce Welfare and Can Enforcement Improve It?’ Canadian Journal of Economics 27:157-174.

Marion, J., and Muehlegger, E., 2008. 'Measuring Illegal Activity and the Effects of Regulatory Innovation: Tax Evasion and the Dyeing of Untaxed Diesel'. Journal of Political Economy 116:633-666.

Miljkovic, D., and Zhuang, R., 2007. 'The exchange rate pass-through into import prices: The case of Japanese meat imports'. A paper presented at the American Agricultural Economics Association Annual Meeting, Portland, Oregon.

Mishraa, P., Subramanianb, A., and Topalovac, P., 2008. 'Tariffs, enforcement, and customs evasion: Evidence from India'. Journal of Public Economics 92:1907-1925

Obara, K., Dyck, J., and Stout, J., 2003. 'Pork Policies in Japan', in: Electronic Outlook Report from the Economic Research Service, No. LDPM105-01. United States Department of Agriculture.

Ohtani, A., Shiratsuka, S., and Shirota, T., 2003. 'Kaw' (The decline of exchange-rate pass-through: Examination of wholesale price level in Japan'. Kinyu Kenkyu (Finance Research) 22:59-90 (in Japanese).

Ono, M., 2007. 'Exchange rate pass-through into import prices of materials for processed marine products: A time-series analysis of the bank of Japan's import price index'. Annual Research Report of Fukushima University 3:11-15.

Pitt, M.M., 1981a. 'Smuggling and price disparity'. Journal of International Economics 11, 447458.

— 1981b. 'Alternative Trade Strategies and Employment in Indonesia' in: Krueger A.O., Lary H.B., Monson T. and Akrasanel N. (eds.) Trade and Employment in Developing Countries. University of Chicago Press, Chicago, 181-237.

Rezitis, A.N., and Brown, A.B., 1999. Pass-Through of Exchange Rates and Tariffs in Greek-US Tobacco Trade. Agricultural Economics 21:269-277.

The Forum for Considering Import \& Distribution System of Meat, 2007. 'Butaniku ga Kieru: Sagakukanzei ga Nihon no Shokutaku o Hakai Suru'(Disappearance of Pork Meat: the Variable Tariff Levy will Destroy the Dinner Tables in Japan). Bijinesu Sha, Tokyo.

Slemrod, J., Blumenthalb, M., and Christianc, C., 2001. 'Taxpayer response to an increased probability of audit: evidence from a controlled experiment' in Minnesota Journal of Public Economics 79:455-483.

Tanaka, M., and Mori, H., 2001. 'Economic Analysis of Japanese Pork Import Regulations'. Proceedings of annual conference of the Agricultural Economics Society of Japan, 175-177.

Thursby, M., Jensen, R., and Thursby, J., 1991. 'Smuggling, Camouflaging, and Market Structure'. Quarterly Journal of Economics 106:789-814.

Yang, D., 2008. 'Can enforcement backfire? Crime displacement in the context of customs reform in the Philippines'. Review of Economics and Statistics 90:1-14. 
Winkelmann, L., and Winkelmann, R., 1998. 'Tariffs, quotas and terms-of-trade: The case of New Zealand.' Journal of International Economics 46:313-332.

\section{Data Appendix}

\section{Trade Statistics of Japan}

The monthly information for the declared pork parts imports are obtained from the Trade Statistics of Japan published by the Ministry of Finance (http://www.customs.go.jp/toukei/ info/index.htm). The Harmonised System codes for the frozen meat of pork are 020329021 and 020329022 and correspond to other pork meats, which exclude dressed carcasses and hams, shoulders and cuts thereof, with bone in.

\section{Denmark customs data}

The monthly Denmark custom data is obtained from the StatBank of the Statistics Denmark. (http://www.statbank.dk/statbank5a/default.asp?w=1024).

I combined 11 categories of pork meats that begin with Frozen. In practice, nearly all of frozen meat is reported under the category Frozen boneless meat of domestic pork (excluding bellies streaky and cuts thereof).

\section{Exchange rates}

Monthly exchange rates are obtained from International Financial Statistics published by the International Monetary Fund.

\section{Notes}

1 For a collection of precursors of the contemporary research on tariff evasion, see Bhagwati (1974).

2 The extensive literature on the exchange rate pass-through indicates that there are substantial departures from the perfect competition in some of the international markets and that the degree to which the change in exchange rate is passed through to the price in the destination market is affected by the pricing power of the exporter (Feenstra, 1995). The approach would be sensible when the market is approximated by a long-run equilibrium with a constant marginal cost and free entry. See also the discussion by Besley and Rosen (1999).

3 In these studies, different types of behavioural responses are expected to weaken the response of some variables to taxes. To identify the behavioural response, the estimate of the tax effects are compared with a benchmark for which the magnitudes are theoretically equivalent in the absence of the particular behavioural response. To identify the impact of tax salience, Chetty, Looney, and Kroft (2007) compare the responses of beer demand to exercise tax (salient tax) and sales tax (less salient). To identify the effects of tax evasion, Marion and Muehlegger (2008) compare tax and (wholesale) price elasticity of diesel fuel retail demand.

4 The figure includes measures in form of tariffs or quantitative restrictions, and is based on notification by WTO members to the WTO - (http://www.wto.org/english/tratop_E/safeg_e/ safeg_e.htm\#statistics, accessed September 2, 2009). The Japanese safeguard has some distinct features since it is permitted under a separate agreement (see Obara, Dyck and Stout, 2003).

In 1990, the import and domestic production of pork was 342 thousand tons and 1,088 thousand tons respectively. In 2007, the import and domestic production of pork was 879 thousand tons and 869 thousand tons respectively. 

See, for example, the Editorial in the International Herald Tribune, November 17, 2006.

The Japanese pork industry was politically active in the mid-2000s. The domestic swinery formed the Japan Pork Producers' Association in 2006. The pork importers formed in 2006 a NPO that lobby for a pork tariff reform.

To my knowledge, Tanaka and Mori (2001) is the only empirical study on the variable levy, focusing on the tax avoidance through mixing strategy to be discussed below. In a book published by an interest group that calls for a pork tariff reform, a simple price disparity analysis has been considered (The Forum for Considering Import \& Distribution System of Meat, 2007).

A response by the head of the Agricultural Production Bureau in the Ministry of Agriculture, Forestry and Fishery at the Diet Committee Meeting on Agriculture, Forestry and Fishery, August 4, 2005. Translation by this author.

A large number of previous studies examine tax avoidance by multinational corporations (for example Gordon and Hines, 2002) and evasion by individuals (for example Andreoni, Erard, and Feinstein, 1998), but a relatively smaller number of studies concern outright evasion by firms.

1 For a nice discussion on the importance of behavioural response in the context of elasticity of income to taxes, see Gordon and Slemrod (2000).

2 Kaku and Fukase (2002) provide a descriptive study on the swine markets in Japan. Obara, Dyck, and Stout (2003) describe the Japanese government policies on swine.

3 The strategy is permitted according to a Japanese tax official contacted by this author.

4 From January 1995 to November 2008, 89 safeguards were imposed around the world (http:// www.wto.org/english/tratop_e/safeg_e/safeg_e.htm\#top, accessed May 11, 2009).

5 Based on a headline search of financial press (Nibon Keizai Shimbun, Nikkei Sangyo Shimbun). The largest evasion is 10.48 billion yen in the late 2006 .

For a centralised data source, see Agriculture \& Livestock Industries Corporation (http://lin.lin. go.jp/alic/statis/dome/data2/e_nstatis.htm, Accessed May 12, 2009).

Meat processing companies are likely to have a stronger bargaining power over trading intermediaries owning to the concentration in the downstream industry. Thus, contract prices in the over-thecounter trade are likely to reveal the effects of evasion since the benefits of tax saving through evasion would be passed onto buyers.

von Cramon-Taubadel (1997) examines wholesale and retail prices of pork in Germany using a cointegration regression.

9 Dicky-Fuller unit root tests on the logarithmic of average price in a specification with time trends reject the unit root hypothesis at the 5 per cent level in only 1 out of 37 instances. I therefore accept the null hypothesis of the log price being nonstationary, but, as in Campa and Goldberg (2005), with caution about the power of the test. The Engle-Granger test rejected the null of no cointegration of the prices of belly and tenderloin, so I take the two series to be co-integrated, once again with caution.

If profit earned by trading intermediaries are affected by SG, their stock prices should be influenced by a surprise invocation of SG. A direct approach to check whether the importers adjust margin would be to examine the response of stock prices, but to my knowledge, no specialized trader of pork is publicly listed in the Japanese stock market.

In addition, Rezitis and Brown (1999) examine Greek tobacco export to the United States, and their estimates imply symmetry.

2 Another explanation is the inflow of high-value meat through the mixing strategy. While the explanation is consistent with the depressed price in the intermission of SG, it would not account for the rise in January-March. As discussed below, the mixing strategy would not have been prevalent in the sample period.

3 A statement by Chizuko Takahashi (Japanese Communist Party) at the Diet Committee Meeting on Agriculture, Forestry and Fishery, May 17, 2005.

I have tried nesting the null of no evasion into the cointegration analysis with a structural break. The test is based on a comparison of the implied change in the tenderloin price implied by the estimate 
of cointegrating vector with the expected price change based on a range of TRPT coefficients. The implied change is evaluated at the mean of belly price. The results are hard to interpret since the power of the test is likely to be low due to the imprecise estimates arising from a shorter time series (2001:2-2005:3).

25 A ruling on an evasion case at the Tokyo District Court made in December 22, 2005 found that the case involved ordering forged invoice from a company in Taiwan, clearing customs under the name of a shell company, and changing ownership through a number of shell companies.

26 Based on the shipping schedule posted on the Nippon Yusen Kaisha's website (accessed Dec. 1, 2008).

27 The Wall Street Journal (Eastern Edition), Nov. 1, 2001. 
Asia Pacific Economic Papers

\section{Previous Asia Pacific Economic Papers}

381 Are the East Asian Currencies Still Misaligned? An Analysis Based on Absolute ppp-Income Relationship using Panel Data

Taizo Motonishi, 2009

380 Is Foreign Aid a Vanguard of Foreign Direct Investment? A Gravity-Equation Approach Hidemi Kimura and Yasuyuki Todo, 2009

379 Rain, Elections and Money: The Impact of Voter Turnout on Distributive Policy Outcomes in Japan Yusaku Horiuchi and Jun Saito, 2009

378 Japanese FDI in China: determinants and performance Shiro Armstrong, 2009

377 Expansion Abroad and Jobs at Home: Evidence from Japanese Multinational Enterprises Nobuaki Yamashita and Kyoji Fukao, 2009

376 Should Australia Encourage Developing Countries to Adopt Competition Laws? Henry Ergas, 2008

375 Will New Trends in Foreign Direct Investment Change the Structure of Intra-industry Trade between China and Japan?

Tao Tao, 2008

374 Competition Policy in ASEAN: Case studies Johannah Branson, 2008

373 Can the New Antimonopoly Act Change the Japanese Business Community? The 2005 Amendment to Antimonopoly Act and Corporate Compliance.

Kazukiyo Onishi, 2008

372 Immunising future trade against protectionists: preventing the emergence of more sensitive sectors Andrew Elek, 2008

371 Tax law asymmetries and income shifting: evidence from Japanese Capital KEIRETSU Kazuki Onji and David Vera, 2008

370 The response of firms to eligibility thresholds: evidence from the Japanese value-added tax Kazuki Onji, 2008

369 China and East Asian Energy: Prospects and Issues Vol. 1 \& 11 Peter Drysdale, Kejun Jiang and Dominic Meagher, 2008

368 Measuring trade and trade potential Shiro Armstrong, 2007

367 APEC and infectious disease: meeting the challenge Joel Gilbourd, 2007

366 The flow of funds through a government - A case study on Japan Jun Ikeda, 2007

365 The puzzle of small farming in Japan Yoshibisa Godo, 2007

364 How should one evaluate fiscal conditions? A study based on the comparison between Japan and Australia Jun Ikeda, 2007

363 Political institutions and distributive politics in Japan: getting along with the opposition Yusaku Horiuchi, 2007

362 Negotiating the Australia-Japan basic treaty of friendship and cooperation: reflections and afterthoughts Garry Woodard, Moreen Dee and Max Suich, 2007

361 China and East Asian energy: prospects and issues Vol. 1 Peter Drysdale, Kejun Jiang and Dominic Meagher, 2007 
Annual subscription rate for up to eight issues:

Individuals A $\$ 65.00$ (includes GST) A \$60 (overseas)

Institutions A\$110.00 (includes GST) A \$100 (overseas)

\title{
Cost for single issues:
}

\author{
A $\$ 16.50$ (includes GST) A $\$ 15.00$ (overseas) \\ A $\$ 10.00$ (Students) \\ No postage required within Australia
}

\section{Available from:}

Centre Administrator

Australia-Japan Research Centre

Crawford School of Economics and Management

ANU College of Asia and the Pacific

The Australian National University

Canberra ACT 0200, Australia

Facsimile: (61 2) 61250767

Telephone: (61 2) 61253780

Email: ajrc@anu.edu.au

URL: http:/www.crawford.anu.edu.au 